\title{
MIXED SUPPORT FOR SPATIAL HETEROGENEITY IN SPECIES INTERACTIONS: HUMMINGBIRDS IN A TROPICAL DISTURBANCE MOSAIC
}

\author{
Peter Feinsinger, William H. Busby, ${ }^{*}$ K. Greg Murray, ${ }^{*}$ James H. Beach, ${ }^{*}$ \\ Willow Z. Pounds, $\dagger$ and Yan B. Linhart $\dagger$ \\ Department of Zoology, University of Florida, Gainesville, Florida 32611; \\ †Department of Evolutionary, Population, and Organismal Biology, \\ University of Colorado, Boulder, Colorado 80309
}

Submitted July 15, 1985; Revised August 8, 1986, and February 17, 1987; Accepted May 29, 1987

The spatial heterogeneity of natural landscapes structures the distributions of species and relationships between species (MacArthur and Pianka 1966; Wiens 1976, 1986; Pickett and White 1985). Patchiness of habitats can affect the dynamics of populations (Reddingius and den Boer 1970; Strong 1983; Strong and Antolin, in press) and the dynamics of interactions between populations, such as exploitation (Huffaker 1958; Gurney and Nisbet 1978), competition (Levin 1974; Chesson and Case 1986), and mutualism (Thompson 1982; Barton 1986). Even the nature of coevolution among species may vary among patch types (Thompson 1982).

Most frequently, environmental patchiness is caused by disturbance. Many natural landscapes experience frequent small-scale disturbances, resulting in mosaics of recently disturbed patches and patches undisturbed for some time (Whittaker and Levin 1977; White 1979; Sousa 1984b; Pickett and White 1985). Biological effects of disturbance mosaics range from slight to profound, depending on the scale, frequency, and intensity of disturbances (Connell and Slatyer 1977; Connell 1978). The overall effect is to loosen or disrupt the species interactions, or interactions between species and abiotic resources, that characterize undisturbed habitat. One result is the release of critical resources, for example nutrients and sunlight, previously in short supply. If organisms or propagules that can exploit these resources are available, disturbance may increase the density of organisms, leading to regenerating patches that are pockets of high productivity and intense interactions (Connell and Slatyer 1977; Canham and Marks 1985; Sousa 1985; Blake and Hoppes 1986). The "loosening" process may also have other effects on resource use: responses of individuals, populations, or species assemblages to resources in disturbed sites may be more flexible and less precise than those in

\footnotetext{
* Present addresses: W.H.B., The Nature Conservancy, Kansas Biological Survey, Lawrence, Kansas 66045; K.G.M., Department of Biology, Hope College, Holland, Michigan 49423; J.H.B., Missouri Botanical Garden, P.O. Box 299, St. Louis, Missouri 63166-0299.
} 
undisturbed habitat (e.g., Southwood 1977; Brown and Southwood 1983; Brown 1984).

The disturbance-wrought changes in a site's physical and biological conditions may favor invasion by species other than those existing previously, leading to differences in species composition between disturbed and undisturbed sites (Wiens 1976, 1986; Platt and Weis 1977, 1985; Connell 1978; Pickett and Thompson 1978; Brokaw 1985b; White and Pickett 1985). Many studies have concentrated on this community-heterogeneity effect of patch dynamics (Levin 1976; Whittaker and Levin 1977; White 1979; Paine and Levin 1981; Strong 1983, 1986; Sousa 1984b). Populations numerically dominant in long-lived "mature phase" patches (in the sense of Whitmore 1978) are expected to have life history traits and patterns of resource use different from those of populations dominating recently disturbed "gap phase" patches that typically undergo quite rapid regeneration to mature phase.

Of course, disturbance mosaics affect animals as well as plants, either because animals respond directly to heterogeneity in physical conditions or because they respond to disturbance-induced heterogeneity in the distribution of their food resources (Thompson and Willson 1978; Schemske and Brokaw 1981; Willson et al. 1982; Karr and Freemark 1985; Schowalter 1985; Wiens 1985; Blake and Hoppes 1986). Responses of animals to natural disturbance mosaics receive less attention than plant responses, however, and we know of no studies that focus simultaneously on terrestrial plants and animals.

In a year-long field study, we evaluated joint responses of consumers and the plants they pollinate to a natural disturbance mosaic in the tropics (see also Feinsinger et al. 1987; Linhart et al. 1987). We chose a particularly well studied consumer group (nectar-feeding birds) whose morphology, behavior, and population ecology are especially closely linked to their food resources and whose use of those resources is easily quantified. For a landscape mosaic, we chose a Neotropical cloud forest that, like other forests, is subject to frequent natural disturbance.

\section{THE CLOUD-FOREST MOSAIC AND ITS POSSIBLE EFFECTS ON SPECIES INTERACTIONS}

Recent research (Richards and Williamson 1975; Whitmore 1978, 1982; Denslow 1980; Hartshorn 1980; Lang and Knight 1983; Brokaw 1985a,b; Hubbell and Foster 1986) has demonstrated that many tropical forests are mosaics of maturephase patches, relatively small gap-phase patches created by falling trees and branches (hereafter, "treefalls"), and larger gap-phase patches created by disturbances such as landslides (Garwood et al. 1979). Building-phase patches (Whitmore 1978) are the results of earlier disturbances. Although a continuum of patch sizes exists, operationally the forest can be treated as a continuous canopy broken by disturbed patches (hereafter, "gaps") of two size classes, moderate and large. The physical conditions in large gaps are apt to differ substantially from those of canopied forest, with conditions in moderate sizes of gaps intermediate (e.g., see Schulz 1960; Connell and Slatyer 1977; Connell 1978; White 1979; Denslow 1980; Chazdon and Fetcher 1984). All sizes of gaps eventually merge back into the surrounding forest as the canopy is reestablished (see also Hallë et al. 1978). 
The nature of the ecological succession during gap regeneration is highly controversial (McIntosh 1980). We bypass the controversy by emphasizing spatial rather than temporal aspects of disturbance (see also Levin 1976; Whittaker and L.evin 1977; MeIntosh 1980; Sousa 1984b). From the viewpoint of a population inhabiting the mosaic, the landscape consists of recently created gaps (of various sizes), in which current conditions are unlikely to persist, and habitat patches undisturbed for some time, in which current conditions have persisted throughout the recent pist and are likely to last until the next disturbance episode (Levin 1976; Pickett 1976; McIntosh 1980; Sousa 1984b).

To evaluate the hypothesis that disturbance "loosens" species interactions, we asked if foraging-related traits of nectar-feeding birds varied among three patch types: large gaps, small gaps, and forest with canopy intact. Variables assessed for spatial heterogeneity included the density of food resources, temporal variation in food density, and temporal variation in consumer demand. We examined ecological specialization (sclectivity among possible resources) by the average consumer population in each patch type. To assess noise in interspecific relationships, we detcrmined whether diets of different bird populations were haphazard in relation to one another, and calculated the goodness of fit between collective foraging by all consumer populations and the nectar resources available. To cvaluate the extent of community heterogeneity, we asked whether disturbance favored different consumer species than those typical of intact forest, and examined morphological and behavioral phenotypes among birds of each patch type for traits associated with opportunistic, generalized foraging.

\section{METHODS}

\section{Choice of System}

Nectar-feeding birds are vagile and easily capable of traversing several patch boundaries in the course of a foraging bout, but this does not detract from their usefulness for evaluating responses to disturbance. First, many other groups of vagile animals are known to differentiate between undisturbed forest and patches resulting from anthropogenic disturbances (e.g., Adams 1908; Odum 1950; Johnston and Odum 1956; Karr 1968; Janzen 1973; M'Closkey 1975; Teraguchi et al. 1977; Väisänen and Järvinen 1977; Southwood et al. 1979, 1983; May 1982; August 1983; Brown and Southwood 1983). With two exceptions (Willson et al. 1982; Blake and Hoppes 1986), the few previous studies on vagile animals occupying natural disturbance mosaics have come to similar conclusions (e.g., Schemske and Brokaw 1981). Likewise, Karr and Freemark $(1983,1985)$ have documented subtle population- and community-wide responses of tropical birds to natural habitat heterogencity. Thus, although the grain of a disturbance mosaic is much less coarse for relatively large, vagile consumers such as birds than for small consumers (such as insects or intertidal animals), the mosaic could still be reflected in population and community patterns among the large consumers (Wiens 1976, 1986).

Second, for Neotropical nectar-feeding birds in particular, species composition 
and species interactions are known to differ between mature forest and anthropogenic second-growth habitat (Feinsinger and Colwell 1978; Stiles 1978, 1981; Feinsinger 1983). For example, hummingbirds with long bills specialized for extracting nectar from long-tubed flowers are most typical of habitats undisturbed by man, whereas opportunistic hummingbirds with short bills predominate in second growth. Sometimes this response reflects the distribution of particular flowering plants, but sometimes hummingbird species composition changes from habitat to habitat independently of floral species composition. Furthermore, foraging behavior of individual hummingbirds can vary with a change in the nature of the habitat, resources, or competitive environment (Feinsinger 1976; Stiles 1981). Thus, even if bird species composition were to remain constant, collective properties of nectar-feeding bird assemblages could vary among patches.

\section{Field Procedure}

The Monteverde Cloud Forest Reserve (ca. 4000 ha) straddles the continental divide of the Cordillera de Tilarán in northwestern Costa Rica and is continuous with other forests blanketing the crest and Caribbean slope of the cordillera. Except for a livestock trail and several foot trails, the Cloud Forest Reserve has been little influenced by humans. The forest is strongly influenced, though, by northeastern trade winds, which carry clouds and mist over the divide, and the forest remains wet year-round. Trade winds are also responsible for high rates of disturbance. Canopy gaps created by falling limbs and trees are frequent (Lawton and Dryer 1980). Murray (1986) estimated that such events disrupt about $1.5 \%$ of the canopy cover per year. Treefall gaps range from smaller than $10 \mathrm{~m}^{2}$ to larger than $500 \mathrm{~m}^{2}$, with a median around $35 \mathrm{~m}^{2}$. Landslides, which occur on steep slopes, are much less frequent than treefalls but disrupt larger areas. Landslides occurring on the Pacific-facing slopes typically devastate an area of about $16 \mathrm{~m} \times$ $100 \mathrm{~m}$. Landslides consist of a central swath (5-10 m wide) from which both vegetation and soil cover have been swept and of a belt on either side that still retains some soil and fragments of the original vegetation. Revegetation on both treefall gaps and landslide gaps involves many plant species adapted for hummingbird pollination.

In June 1981 we set up study plots in mature patches, small gaps, and large gaps. Four plots in understory of canopied forest totaled $7280 \mathrm{~m}^{2}$. Six plots, totaling $2300 \mathrm{~m}^{2}$, were in gaps that had been created by two or more trees falling 1 to $3 \mathrm{yr}$ earlier. For reasons of personal safety, we did not use landslide scars as principal study plots, but instead cleared (in January 1980) four large gaps along the livestock trail, close to other study sites. These "cutovers," which totaled $7380 \mathrm{~m}^{2}$ exclusive of the bare trail down the center of each, differed from true landslide scars in slope and soil conditions. The high frequency of stump-sprouts in the cutovers may have led to some species' having abnormally high flower densities for naturally occurring large canopy gaps (Linhart et al. 1987). Nevertheless, during 1982-1983, monthly comparisons of cutover plots with nearby landslide scars revealed that vegetation was quite similar. There were no floristic anomalies so great as to disqualify the cutovers for use as experimental "large 
gaps." "They resembled the nearby landslide scars in size, shape, and important physical features (e.g., the muddy 5-m-wide trail down the center was analogous to the barren strip in the center of a recent landslide scar, while the belts of cutover vegetation resembled landslide edges). Insolation, physiognomy and species composition of vegetation, and composition of bird assemblages were similar between the cutovers and naturally occurring large gaps.

Each month, from July 1981 through June 1982, on each of the 14 study plots we censused all flowers of species ever used by nectar-feeding birds. Also, on 1 day per patch type per month, we assessed nectar standing crops at 2-h intervals from dawn through noon, using calibrated microcapillary tubes and hand refractometers. We took a random sample of 4-20 (usually 15) different flowers per interval in each of the 1-3 most abundantly flowering plant species in that patch type. The mean for each sample was compared with data on baseline rates of nectar secretion for that plant species, which we obtained using standard techniques (see Feinsinger et al. 1982, 1985). From this comparison, we estimated the proportion of nectar consumed out of the volume potentially available if none had been removed that day or (for flowers lasting longer than 1 day) on previous days.

We mist-netted birds for 2 days for each patch type each month, rotating the study sites used. We marked each hummingbird netted with leg tags (Stiles and Wolf 1973), weighed it to the nearest $0.01 \mathrm{~g}$, and measured wing chord and total culmen (culmen from base; Baldwin et al. 1931) to the nearest $0.05 \mathrm{~cm}$. We also marked the few other nectar-feeding birds netted.

To estimate use of nectar resources by each hummingbird population in a given month, we tallied bird visits to every appropriate plant species flowering in each patch type. Plant species flowering in more than one of the three patch types were observed separately in each. Each patch type's three most abundantly flowering plant specics received at least three replicate observations (in different study sites when possible) that month. Observations began at dawn and lasted $6 \mathrm{~h}$. During an observation (which sometimes included more than one plant species), we noted every bird visit to flowers, recording the number of flowers probed and the cumulative time spent probing. Over the year we accumulated 4218 hours of observation and tallied 12,814 flower-probes.

Although most investigations were confined to the herb-shrub layer in the study sites described above, Busby (MS) also examined closely the availability of, and visits to, flowers of eight species of epiphytic Ericaceae, which provided the vast majority of nectar resources for forest canopy birds.

In August 1982, we tested the prediction that individual nectar-feeding birds occupying large gaps are relatively opportunistic compared with birds in forest understory. We simultaneously introduced novel nectar resources into patches of each type and noted the rapidity with which local birds discovered these. In one set of experiments, we used large flowering branches of Hamelia patens (Rubiaccac), a shrub species common $2 \mathrm{~km}$ from the cloud forest and patronized by short-billed hummingbirds there. In the other set of experiments, we used inflorescences of banana (Musa acuminata), known to attract at least one species of long-billed hummingbird on farms $2 \mathrm{~km}$ away. The experimentally introduced flowers were maintained in water-filled containers conspicuously mounted $2 \mathrm{~m}$ 
from naturally occurring flowering plants known to be exploited by local hummingbirds. We watched the introduced plants during the first $6 \mathrm{~h}$ of daylight for at least 3 days following the introduction.

\section{Analyses}

With few exceptions, techniques for analysis follow those used in previous studies (Feinsinger et al. 1985). To estimate use of nectar resources by each bird species within a given patch type, we treat each plant species as a separate resource state. For each resource state $r$, we estimate its daily use $U_{i r}$ by bird population $i$, defined as the total number of visits made by $i$ in the four to six study plots of that patch type, by

$$
U_{i r}=V_{i r} F_{r} / O_{r},
$$

where $V_{i r}$ is the total number of visits bird species $i$ made to the flowers we observed (summed over replicate observations); $O_{r}$ is the number of flowers open that day on the plant or plants observed (thus, $V_{i r} / O_{r}$ is visits per flower per day); and $F_{r}$ is the total number of open flowers in resource state $r$ that we counted that month throughout the four to six study plots of that patch type. In calculating this measure, we include all nectar visits to flowers, whether legitimate (i.e., entering through the opening of the corolla tube) or illegitimate (i.e., piercing the corolla tube or using an existing hole).

Unweighted $U_{i r}$ is used in some calculations (e.g., eq. 5), but for most calculations, flowers of different species are weighted by an estimate of their nectar value as perceived by hummingbirds: the mean number of seconds a hummingbird making a "legitimate" visit kept its beak in a flower of that species (see Feinsinger and Swarm 1982). Weighting factors range from 0.3, for small insect-pollinated flowers with little nectar, to 1.7 . Factors are highly correlated with mean daily nectar production per flower $\left(r_{s}=0.592, P<0.001, n=37\right.$ species $)$ and are deemed more accurate indexes of true nectar value, which is a function not only of baseline secretion rates but also of the pattern of birds' visits (Gill 1978). For those plant species receiving frequent visits from both long- and short-billed hummingbirds, there were no significant differences between the two bird groups in the time spent at each flower. Hence, the same weighting factor is used regardless of the identity of the bird.

To estimate nectar abundance or weighted flower numbers $\left(F_{r w}\right)$, we multiply the number of flowers in that resource state $\left(F_{r}\right)$ by the appropriate weighting factor. The sum of $F_{r w}$ for a given patch type, over all plant species, reflects the total supply of nectar, or the number of resource (nectar) units available that month to birds. We also define three overlapping subsets of total nectar supply: the subset of flowers used by long-billed hummingbirds, which excludes data for several short-flowered plant species that these birds rarely or never used; the subset of flowers used by (most) short-billed hummingbirds, which excludes data for several long-flowered plant species whose nectar was inaccessible by normal feeding modes; and the subset of flowers used by short-billed hummingbirds that 
frequently pierce flower corollas, which excludes only those few species of long flowers whose morphologies preclude nectar robbery.

Diversity of the nectar resource base is measured with the inverse of Simpson's index, or

$$
\text { diversity }_{R}=1 / \sum_{r} p_{r}^{2} \text {, }
$$

where $p_{r}=F_{r w} / \Sigma_{r} F_{r w}$.

Use weighted for nectar value $\left(U_{i r w}\right)$ is then use (eq. 1) multiplied by weighting factor for resource state $r$.

The relative impact of bird population $i$ on nectar resources, or demand by $i$, is then

$$
\text { demand }_{i}=\sum_{r} U_{i r w} .
$$

We also sum the demands among different species in order to obtain the demand by all short-billed hummingbirds, the demand by all long-billed hummingbirds, or, by summing the demands by all bird populations present in a patch type-month combination, the guild demand $\left(\Sigma_{i} \Sigma_{r} U_{i n v}\right)$.

Species diversity in demand of nectar-feeding birds is then measured with the inverse of Simpson's index, or

$$
\operatorname{diversity~}_{s}=1 / \sum_{i} p_{i}^{2},
$$

where $p_{i}=\Sigma_{r} U_{i r w} / \Sigma_{i} \Sigma_{r} U_{i r w}$.

Diet breadth (niche breadth along the diet axis) of a given population is the proportional similarity between the flowers available and the flowers used, unweighted by nectar value (for rationale, see Feinsinger and Swarm 1982; Feinsinger et al. 1985), or

$$
\text { diet breadth } \text { }_{i}=\sum_{r=1}^{R} \min \left(\frac{U_{i r}}{\sum_{r} U_{i r}}, \frac{F_{r}}{\sum_{r} F_{r}}\right),
$$

where $R$ is total number of resource states available in that patch type that month and min signifies the lesser of the two proportions (Feinsinger et al. 1981). Mean dict breadth is the mean of all nectar-feeding bird populations present, with each weighted by its demand as defined above. Guild diet breadth, in contrast, is calculated with the collective foraging of all nectar-feeding birds at each resource state, or

$$
\text { diet breadth } s=\sum_{r=1}^{R} \min \left(\frac{\sum_{i} U_{i r}}{\sum_{r} \sum_{i} U_{i r}}, \frac{F_{r}}{\sum_{r} F_{r}}\right) \text {. }
$$


Both mean and guild diet breadth use $U_{i r}$ and $F_{r}$ at all possible nectar resources, as defined above.

Pairwise diet overlap between bird populations $i$ and $k$ is calculated with an analogous proportional similarity index:

$$
\text { diet overlap }=\sum_{r} \min \left(p_{i r w}, p_{k r w}\right),
$$

where $p_{i r w}=U_{i r w} / \Sigma_{r} U_{i r w}$ and $p_{k r w}=U_{k r w} / \Sigma_{r} U_{k r w}$. More relevant to a bird population, though, is diet overlap with the collective foraging of all other nectar feeders (Feinsinger 1976; Feinsinger and Swarm 1982; Thomson and Rusterholz 1982). To obtain diet overlap on a given bird population by the remainder of the nectar-feeding bird guild, we used equation (7), where $U_{k r w}$ is now the weighted use of resource state $r$ by all birds except species $i$. We report this measure below with one exception (pairwise overlap between the two principal hummingbird species). The mean diet overlap is the weighted mean, over all populations present in a habitat-month combination, of the overlap experienced by each population, weighted by that population's demand.

The intensity of exploitative interspecific competition is not indicated by diet overlap but rather by the "co-occurrence coefficient" (Rathcke 1976) or "mean interspecific crowding" (Hurlbert 1978, eq. 15), $z$ :

$$
z_{i(k)}=\sum_{r}\left(\frac{U_{i r w}}{\sum_{r} U_{i r w}}\right)\left(\frac{U_{k r w}}{F_{r w}}\right),
$$

where $U_{k r w}$ is the weighted use of resource state $r$ by all nectar-feeding birds other than species $i$, and $\Sigma_{r} U_{i r w}$ is the demand by species $i$ as described above. Here, $z$ specifically measures the frequency with which birds of other species probe flowers used by species $i$, weighted by food value. Thus, a high value for $z$ indicates that other species visit those flowers frequently, such that most nectar potentially available to population $i$ in that patch type must actually be consumed by other species and the competitive load is high. Mean $z$ per patch type is then the mean (weighted by demand) over all bird species present that month. Note that neither $z$ nor diet overlap indicates the impact of interference competition.

For statistical comparisons of the various indexes among patch types, we used the Friedman test to compare median values (Siegel 1956), with patch types as columns and months as rows. All $n$ 's $=12$ except for analyses on one species (Lampornis calolaema) that was not always in every patch type; for this species, we used data from only the 10 mo that it was simultaneously present in all habitats. When results from the Friedman test were significant, we made pairwise comparisons between each two patch types (Hollander and Wolfe 1973, p. 151). To compare sample variability between pairs of habitats, we used the Miller jackknife test (Hollander and Wolfe 1973). Data expressed as proportions were arcsin transformed first. In most cases we compared variation in the absolute value of a variable. For those cases in which the relative extent of variation was of 
greater interest (see Van Valen 1978), we added 1 to each variate and then log transformed the result before running the Miller test.

Treating each month's data as a replicate sample verges on temporal pseudoreplication (Hurlbert 1984), because resources and hummingbird foraging patterns in a particular month are unlikely to be entirely independent of resources and hummingbird foraging patterns in the same patch in the preceding and following months. Considering the fairly rapid turnover in floral resources (Linhart et al. 1987) and the extreme flux (even during a given day) in hummingbirds within a given patch, however, the statistical comparisons we report should be quite unbiased.

RESULTS

\section{Characteristics of Nectar Resources}

Floral diversity and density varied somewhat among the three patch types: understory of mature forest (henceforth termed "forest"), gaps resulting from trecfalls ("trecfalls"), and larger gaps ("cutovers"). The density of nectar resources was lowest in forest (table 1). Treefalls also held a greater diversity of nectar resources than did cutovers. In no patch type, though, did nectar density vary by more than a factor of 4 over the year (fig. 1), and there was no significant difference in the relative extent of variation (table 1 ).

The subset of flowers used by most short-billed hummingbirds was also most dense in treefalls but was no more dense in cutovers than in forest (table 1). The subset of flowers used by long-billed hummingbirds was least dense in forest, most dense in treefalls (table 1). As reported in detail elsewhere (Linhart et al. 1987), compared with resources for specialist (long-billed) hummingbirds, the relative abundance of resources for hummingbirds with phenotypes for generalized, opportunistic resource use (short bills) was least in cutovers, greater in treefalls, and greatest in forest.

The proportion of nectar consumed did not vary significantly among patch types. Consumption (mean of sample means per patch type) was $95.2 \% \pm 6.3 \%$ ( $n=25$ sample means) for cutovers, $94.6 \% \pm 2.5 \%(n=23)$ for treefalls, and $95.4 \% \pm 3.3 \%(n=20)$ for forest (Kruskal-Wallis $H=1.427, P>0.30$ ). Furthermore, a hummingbird foraging in different patch types at midday would not have encountered substantial differences in the dispersion of "blank" flowers (sce Feinsinger 1978): the proportion of flowers having no measurable quantities of nectar by noon did not differ significantly among patch types (Kruskal-Wallis $H=3.516, P>0.10)$.

\section{Demand for Nectar}

Because nectar density was higher in treefalls than in either of the other patch types, it is not surprising that demand for nectar (per unit area) was also highest in trecfalls (table 2). Temporal variation in demand, however, was significantly greater in cutovers than in forest (table 2), even though the extent of variation in the resources themselves did not differ among habitats (table 1). 
TABLE 1

Nectar Resources (monthly mean I standard deviation) Available to Birds on Study Plots from July i98i to June I982

\begin{tabular}{|c|c|c|c|c|c|c|c|}
\hline \multirow[b]{2}{*}{ Measure } & \multicolumn{3}{|c|}{ Рatch Type } & \multicolumn{3}{|c|}{ Friedman Test } & \multirow{2}{*}{$\begin{array}{c}\text { PAIRWISE } \\
\text { MILLER TESTS } \\
\text { (RELATIVE } \\
\text { VARIATION)* }\end{array}$} \\
\hline & Cutovers & Treefalls & Forest & $x^{2}$ & $P$ & $\begin{array}{c}\text { Pairwise } \\
\text { Comparisons* }\end{array}$ & \\
\hline \multicolumn{8}{|l|}{ Total resource base $\dagger$} \\
\hline $\begin{array}{l}\text { Flowers per ha } \\
\text { (weighted) }\end{array}$ & $807 \pm 323$ & $1506 \pm 723$ & $260 \pm 114$ & 19.50 & $<0.0001$ & $\begin{array}{l}C=T, T>F \\
C>F\end{array}$ & $\mathrm{C}=\mathrm{T}=\mathrm{F}$ \\
\hline Species diversity $\left(C_{\text {inv }}\right)$ & $3.72 \pm 1.77$ & $5.61 \pm 2.44$ & $3.80 \pm 1.43$ & 8.67 & $<0.02$ & $\begin{array}{l}\mathrm{C}<\mathrm{T}, \mathrm{T}=\mathrm{F} \\
\mathrm{C}=\mathrm{F}\end{array}$ & \\
\hline \multicolumn{8}{|l|}{$\begin{array}{l}\text { Resource base for short- } \\
\text { billed hummingbirds } \ddagger\end{array}$} \\
\hline $\begin{array}{l}\text { Flowers per ha } \\
\text { (weighted) }\end{array}$ & $178 \pm 160$ & $596 \pm 624$ & $107 \pm 41$ & 15.50 & $<0.0005$ & $\begin{array}{l}\mathrm{C}<\mathrm{T}, \mathrm{T}>\mathrm{F} \\
\mathrm{C}=\mathrm{F}\end{array}$ & \\
\hline $\begin{array}{l}\text { Resource base for long- } \\
\text { billed hummingbirds } \S\end{array}$ & & & . & & & & \\
\hline $\begin{array}{l}\text { Flowers per ha } \\
\text { (weighted) }\end{array}$ & $671 \pm 308$ & $972 \pm 315$ & $165 \pm 127$ & 18.17 & $<0.0001$ & $\begin{array}{l}\mathrm{C}<\mathrm{T}, \mathrm{T}>\mathrm{F} \\
\mathrm{C}>\mathrm{F}\end{array}$ & \\
\hline
\end{tabular}

Note.-Numbers of open flowers counted in each plant species were weighted by "nectar value" (see "Methods"). $C_{\text {inv }}$ is inverse Simpson's index (eq. 2). Pairwise comparisons here and in subsequent tables were made only when the results of the Friedman test were significant.

* C, cutovers; T, treefalls; F, forest.

$\dagger$ Total resource base, including any flower species ever visited by any nectar-feeding bird species.

¥ Resource base for short-billed hummingbirds (except Eupherusa eximia, which, along with Diglossa plumbea, also exploited long flowers by piercing the corolla).

\$ Resource base for long-billed hummingbirds, excluding short and insect-pollinated flowers at which these birds rarely or never fed. A few plant species were part of the resource bases for both short- and long-billed species. 
TABLE 2

Demand For Nectar Resources

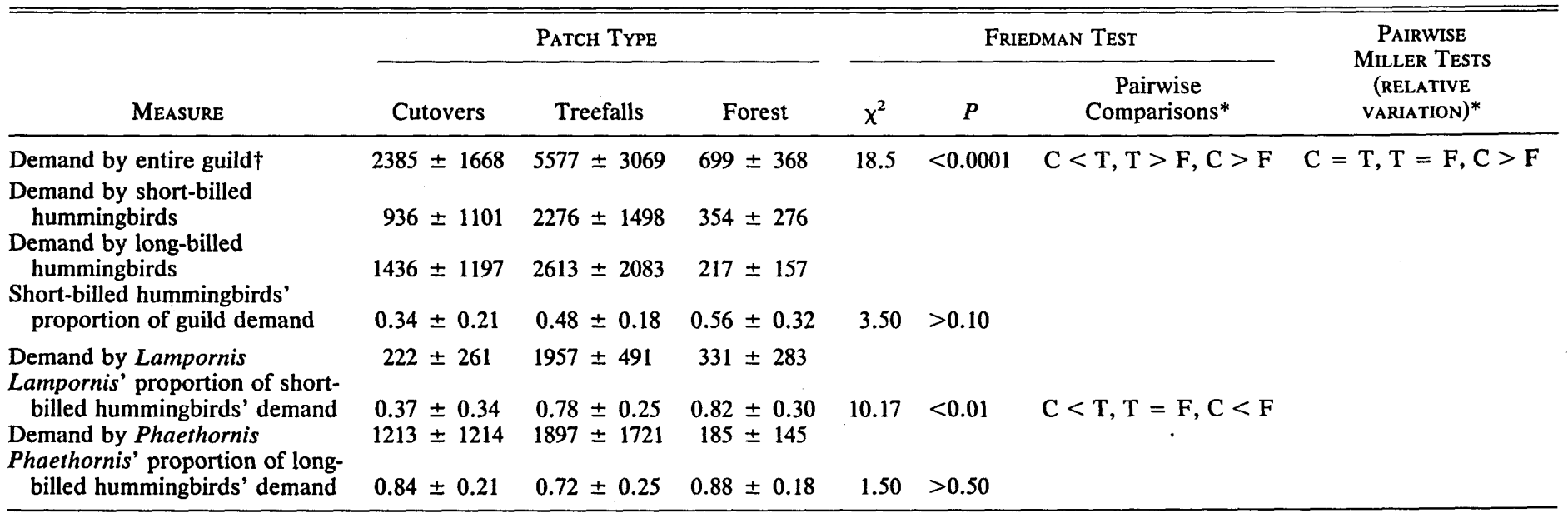

Nore. - See equation (3) and the text that follows it. Values are monthly mean \pm the standard deviation. The units of demand are the numbers of visits to flowers, weighted by the "nectar value" of each flower species visited, per ha.

* C, cutovers; T, treefalls; F, forest.

$\dagger$ Demand by all birds and by the two major subsets from July 1981 to June 1982. 


\section{DENSITY OF NECTAR RESOURCES}

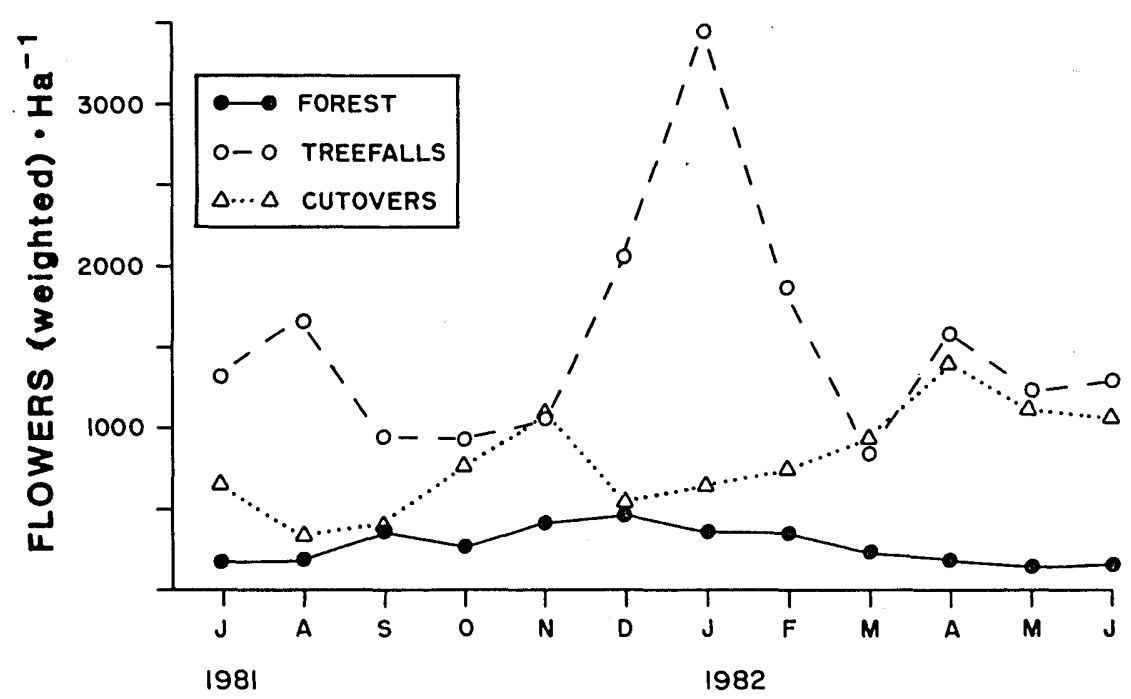

MONTH

FIG. 1.-Density of nectar resources, per unit of area, in the three patch types over the 12 mo of this study. Numbers of flowers in each species were weighted by that species' "nectar value" as defined in text.

\section{Distribution of Species and Phenotypes among Habitats}

In some mosaics, disturbances of increasing size or intensity support increasing numbers of transient or fugitive species (Connell and Slatyer 1977). We observed a total of 10 hummingbird species (5 long-billed and 5 short-billed) and 1 passerine foraging for nectar in the study plots (table 3). Of these, 4 hummingbird species appeared only sporadically and unpredictably, even when appropriate flowers were available: the 2 canopy species Panterpe insignis (a year-round resident) and Elvira cupreiceps (a seasonal migrant), plus 2 true transients with no nearby core populations, Selasphorus scintilla and Eugenes fulgens (although the tally of months present suggests that it is a transient, Doryfera ludovicae actually foraged consistently on its preferred flower species). In addition, we observed a shortbilled hummingbird species known to be extremely opportunistic and migratory, Colibri delphinae, foraging for Cecropia sap on the edge of a cutover plot. We also mist-netted one individual of a long-billed species, Eutoxeres aquila, in a cutover. Thus, transient species tended to occur most frequently in cutovers, and least frequently in forest, but the trend was not marked. Furthermore, the impact of transients was minor; their total demand was less than $1 \%$ of that of other species.

Treefalls supported the highest average diversity (eq. 4) of nectar-feeding birds overall (table 4), and the total number of species was no higher in cutovers than in treefalls. The sparse resources in forest supported the lowest diversity and numbers of bird species. Temporal variation did not differ among patch types for either numbers of species or species diversity (table 4).

Overall, then, different patch types supported only marginally different bird 


\section{TABLE 3}

Birds Observed Foraging on Nectar in Each Habitat's Study Areas FROM JULY I98I TO JUNE 1982

\begin{tabular}{|c|c|c|c|c|c|c|}
\hline \multirow[b]{2}{*}{ Bird Species } & \multicolumn{3}{|c|}{ CULmen Length, cm* } & \multicolumn{3}{|c|}{$\begin{array}{l}\text { Months PRESEnt (MEAN DEMAND } \\
\text { PER UNIT OF RESOURCE) } \dagger\end{array}$} \\
\hline & Males & Females & $\begin{array}{l}\text { Both } \\
\text { Sexes }\end{array}$ & Cutovers & Treefalls & Forest \\
\hline \multicolumn{7}{|l|}{ Short-billed hummingbirds } \\
\hline $\begin{array}{l}\text { Lampornis calolaema } \\
\text { Eupherusa eximia } \\
\text { Panterpe insignis } \\
\text { Selasphorus scintilla } \\
\text { Elvira cupreiceps }\end{array}$ & $\begin{array}{l}2.30(27) \\
2.28(22)\end{array}$ & $\begin{array}{l}2.34(79) \\
2.33(16)\end{array}$ & $\begin{array}{l}2.19(4) \\
1.55(2) \ddagger \\
1.80(5)\end{array}$ & $\begin{aligned} & 11(.28) \\
& 12(.42) \\
& 0 \\
& 3(1.60) \\
& 1(.03)\end{aligned}$ & $\begin{aligned} & 12(1.40) \\
& 9(.28) \\
& 2(.06) \\
& 0 \\
& 0\end{aligned}$ & $\begin{aligned} 11 & (2.07) \\
7 & (.13) \\
2 & (.02) \\
0 & \\
0 & \end{aligned}$ \\
\hline \multicolumn{7}{|l|}{ Long-billed hummingbirds } \\
\hline $\begin{array}{l}\text { Phaethornis guy } \\
\text { Campylopterus hemileucurus } \\
\text { Heliodoxa jacula } \\
\text { Doryfera ludovicae } \\
\text { Eugenes fulgens }\end{array}$ & $\begin{array}{l}4.72(17) \\
3.44(11) \\
2.76(8)\end{array}$ & $\begin{array}{l}4.58(53) \\
3.78(18) \\
2.88(16)\end{array}$ & $\begin{array}{c}3.70(1) \S \\
-\|\end{array}$ & $\begin{aligned} & 12(1.51) \\
& 9(.27) \\
& 3(.06) \\
& 0 \\
& 0\end{aligned}$ & $\begin{aligned} 12 & (1.50) \\
10 & (.37) \\
8 & (.16) \\
3 & (.37) \\
1 & (.30)\end{aligned}$ & $\begin{aligned} 12 & (.68) \\
2 & (.04) \\
3 & (.09) \\
3 & (.34) \\
0 & \end{aligned}$ \\
\hline $\begin{array}{l}\text { Passerine } \\
\text { Diglossa plumbea }\end{array}$ & & & - & $3(.05)$ & $1(.13)$ & $1(.16)$ \\
\hline
\end{tabular}

* Culmen from base (Baldwin et al. 1931) or total culmen.

$\dagger$ Months present out of 12; demand is defined in text, per unit of resource available to any nectarfeeding bird, averaged over the months present.

$¥$ Culmen measurement from birds captured in 1975 , ca. $1 \mathrm{~km}$ from study sites.

$\S$ Culmen measurement from bird captured in 1972, ca. $3 \mathrm{~km}$ from study sites.

"Because $E$. fulgens was not mist-netted, there are no culmen data.

TABLE 4

Species Diversity of Nectar-Feeding Birds (monthly mean \pm STandard deviation) in the Three HABITATS FROM JULY 198I TO JUNE I 982

\begin{tabular}{lcc}
\hline & Species Richness & Species Diversity $\left(C_{\text {inv }}\right)$ \\
\hline Patch type & & \\
$\quad$ Cutovers & $4.5 \pm 1.3$ & $2.06 \pm 0.61$ \\
$\quad$ Treefalls & $4.8 \pm 0.8$ & $2.79 \pm 0.67$ \\
$\quad$ Forest & $3.4 \pm 1.1$ & $1.92 \pm 0.63$ \\
Friedman test & 6.62 & 6.17 \\
$\chi^{2}$ & $<0.05$ & $<0.05$ \\
$P$ & $\mathrm{C}=\mathrm{T}, \mathrm{T}>\mathrm{F}, \mathrm{C}=\mathrm{F}$ & $\mathrm{C}<\mathrm{T}, \mathrm{T}>\mathrm{F}, \mathrm{C}=\mathrm{F}$ \\
Pairwise comparison & $\mathrm{C}=\mathrm{T}=\mathrm{F}$ & $\mathrm{C}=\mathrm{T}=\mathrm{F}$ \\
\hline (absolute variation) & &
\end{tabular}

Nore. $-C_{\text {inv }}$ (eq. 4) is calculated from the species' demands in a given habitat in a given month.

assemblages. In the average month, proportional similarity in bird species composition (based on each species' demand) was $50.5 \%$ (cutovers vs. treefalls), $60.9 \%$ (treefalls vs. forest), or $43.9 \%$ (cutovers vs. forest). Although several bird species appeared to prefer some patch types over others (table 3 ), two hummingbird species (one short-billed and one long-billed) accounted for most flower visits and 
TABLE 5

Numbers of Nectar-Feeding Birds Mist-Netred on Study Plots from June i981 to June 1982

\begin{tabular}{|c|c|c|c|}
\hline \multirow[b]{2}{*}{ Hummingbird Species } & \multicolumn{3}{|c|}{ Numbers of INDIVIdUALS NetTEd } \\
\hline & Cutovers & Treefalls & Forest \\
\hline \multicolumn{4}{|l|}{ Short-billed hummingbirds } \\
\hline Lampornis calolaema & 26 & 43 & 46 \\
\hline Eupherusa eximia & 19 & 18 & 8 \\
\hline Panterpe insignis & 2 & 1 & 2 \\
\hline Elvira cupreiceps & 4 & 1 & 1 \\
\hline SUBTOTAL & 51 & 63 & 57 \\
\hline \multicolumn{4}{|l|}{ Long-billed hummingbirds } \\
\hline Phaethornis guy & 31 & 34 & 19 \\
\hline Campylopterus hemileucurus & 11 & 17 & 4 \\
\hline Heliodoxa jacula & 8 & 11 & 7 \\
\hline Eutoxeres aquila & 1 & 0 & 0 \\
\hline SUBTOTAL & 51 & 62 & 30 \\
\hline TOTAL & 102 & 125 & 87 \\
\hline
\end{tabular}

nectar consumption in all habitats (table 2). Lampornis calolaema males were often territorial at clumps of short flowers, whereas the less aggressive females foraged at a wide variety of short-flowered species. Together they contributed $37 \%$ (cutovers) to $82 \%$ (forest) of the demand by all short-billed hummingbirds. Both sexes of Phaethornis guy foraged at all long-flowered species available and contributed $72 \%$ to $88 \%$ of the demand for all long-billed birds (table 2). Together, these two species accounted for $67 \%$ of the demand by the entire nectar-feeding bird guild in cutover plots, $74 \%$ in treefalls, and $88 \%$ in forest understory. Not only were both species distributed over all patch types, but even individual birds freely traversed patch boundaries on their foraging trips. These results were not artifacts of the somewhat artificial nature of cutovers; they were corroborated by observations made during 1982-1983 on revegetating landslide scars, where Lampornis and Phaethornis, the predominant species, flew freely between flowers on landslide scars and flowers in adjacent forest.

Birds with generalized phenotypes (short bills) did not predominate in disturbances (table 3). In fact, the relative contribution of short-billed hummingbirds to guild demand tended to be least in cutovers, greater in treefalls, and greatest in forest (table 2). Although not significant, this trend was paralleled by a significant increase in the relative numbers of short-billed hummingbirds that we mist-netted (table 5). Short-billed hummingbird "weeds" were largely absent from gap-phase plots but not from the pool of species available: seven species of short-billed hummingbirds frequenting anthropogenic old-field habitats as little as $1 \mathrm{~km}$ distant (Feinsinger 1977) were never observed or mist-netted in any cloud-forest study plot.

\section{Diet Breadths of Species}

Despite similar species and phenotypic composition among patch types, the average hummingbird in each could have responded differently to nectar re- 
sources. A single bird, foraging among several patch types, might use different rules in each, foraging selectively to a greater or lesser degree among available nectar resources and thereby contributing to spatial heterogeneity in populationwide diets. The results of flower-introduction experiments suggest that individual birds foraging in forest were less opportunistic than birds foraging in the other two patch types, whether long or short flowers were involved. In treefalls and cutovers, introduced Hamelia branches were incorporated into foraging routes of Lampornis by the second day following introduction. After 3 days, no birds had discovered the forest introduction, despite the relatively high density of Lampornis there (table 2). Banana inflorescences attracted long-billed Campylopterus in cutovers by the third day following introduction, but banana flowers in treefalls and forest were still ignored by day 4 despite the presence of both Campylopterus and Phaethornis nearby.

This result hints that individual nectar-feeding birds may be more opportunistic in large gaps than in other habitats. It may simply indicate, however, that new flowers are most apparent in open habitats. Measurements on population-level diets do not provide evidence for a link between disturbance and opportunism. In fact, diet breadth of the average hummingbird population was greater in forest than in the other patch types (table 6).

\section{Interspecific Relationships}

Guild diet breadth increased from cutovers to forest (table 6). Diet overlap experienced by the average hummingbird population (table 6) decreased from cutovers to forest. These results were not simply direct consequences of quantitative differences in bird density and diversity, because density and diversity were highest in treefalls, not cutovers (tables 2, 4). Pairwise diet overlap between the two principal species alone was significantly greater in cutovers than in either of the other patch types (table 6).

The intensity of exploitative competition (fig. 2) fluctuated somewhat in all patch types. Competitive intensity was lowest, and varied the least over time, in forest (table 6). Competition experienced by Lampornis was highest in cutovers, whereas competition experienced by Phaethornis was higher in treefalls than in cutovers (table 6).

\section{DISCUSSION}

Nectar-feeding bird assemblages in the Monteverde cloud forest respond in complex ways to the natural disturbance mosaic. The null hypothesis (no difference among patch types) was not rejected in only two cases: (1) in the species we examined, birds consumed nearly all of the nectar produced, regardless of patch type; and (2) temporal variation in the density of food resources did not change with patch type (table 1). These results, coming from a disturbance mosaic closely approximating natural conditions, failed to support the generalization, based on large anthropogenic disturbances, that constancy in the availability of resources to consumers will increase through a secondary succession (Margalef 1963; Odum 1969; Southwood 1977; Brown 1984). Other assemblage-level properties of birds 
TABLE 6

Diet Breadth, Diet Overlap, and Intensity of Exploitative Competition from July i98i to June 1982

\begin{tabular}{|c|c|c|c|c|c|c|c|}
\hline \multirow[b]{2}{*}{ Measure } & \multicolumn{3}{|c|}{ Patch TyPe } & \multicolumn{3}{|c|}{ Friedman Test } & \multirow{2}{*}{$\begin{array}{l}\text { Miller Tests } \\
\text { (ABSOLUTE } \\
\text { VARIATION) }\end{array}$} \\
\hline & Cutovers & Treefalls & Forest & $\chi^{2}$ & $P$ & $\begin{array}{l}\text { Pairwise } \\
\text { Comparisons }\end{array}$ & \\
\hline \multicolumn{8}{|l|}{ Diet breadths* } \\
\hline $\begin{array}{l}\text { Mean diet breadth (eq. 5) } \\
\text { Guild diet breadth } \\
\text { (eq. 6) }\end{array}$ & $\begin{array}{l}0.335 \pm 0.190 \\
0.498 \pm 0.195\end{array}$ & $\begin{array}{l}0.343 \pm 0.058 \\
0.638 \pm 0.140\end{array}$ & $\begin{array}{l}0.511 \pm 0.164 \\
0.740 \pm 0.116\end{array}$ & 6.17 & $\begin{array}{l}<0.05 \\
<0.05\end{array}$ & $\begin{array}{l}\mathrm{C}=\mathrm{T}, \mathrm{T}<\mathrm{F}, \mathrm{C}<\mathrm{F} \\
\mathrm{C}=\mathrm{T}, \mathrm{T}=\mathrm{F}, \mathrm{C}<\mathrm{F}\end{array}$ & \\
\hline \multicolumn{8}{|l|}{ Diet overlaps (eq. 7) } \\
\hline $\begin{array}{l}\text { Mean diet overlap } \dagger \\
\text { Diet overlap between } \\
\text { Lampornis and } \\
\text { Phaethornis }\end{array}$ & $0.397 \pm 0.289$ & $0.226 \pm 0.173$ & $0.087 \pm 0.067$ & 7.17 & $<0.05$ & $\mathrm{C}=\mathrm{T}, \mathrm{T}=\mathrm{F}, \mathrm{C}>\mathrm{F}$ & \\
\hline $\begin{array}{l}\text { Intensity of exploitative } \\
\text { competition, } z \text { (eq. } 8 \text { ) }\end{array}$ & & & & & & & \\
\hline $\begin{array}{l}\text { On "average" popula- } \\
\text { tion } \\
\text { On Lampornis } \\
\text { On Phaethornis }\end{array}$ & $\begin{array}{l}1.07 \pm 0.66 \\
1.42 \pm 1.33 \\
0.90 \pm 0.59\end{array}$ & $\begin{array}{l}1.32 \pm 0.83 \\
0.34 \pm 0.60 \\
1.40 \pm 0.70\end{array}$ & $\begin{array}{l}0.28 \pm 0.26 \\
0.14 \pm 0.18 \\
0.38 \pm 0.37\end{array}$ & $\begin{array}{r}10.17 \\
8.04 \\
10.67\end{array}$ & $\begin{array}{l}<0.01 \\
<0.025 \\
<0.005\end{array}$ & $\begin{array}{l}\mathrm{C}=\mathrm{T}, \mathrm{T}>\mathrm{F}, \mathrm{C}>\mathrm{F} \\
\mathrm{C}>\mathrm{T}, \mathrm{T}=\mathrm{F}, \mathrm{C}>\mathrm{F} \\
\mathrm{C}=\mathrm{T}, \mathrm{T}>\mathrm{F}, \mathrm{C}=\mathrm{F}\end{array}$ & $\mathrm{C}=\mathrm{T}, \mathrm{T}>\mathrm{F}, \mathrm{C}>\mathrm{F}$ \\
\hline
\end{tabular}

NotE.-Values are monthly mean \pm standard deviation.

* Mean diet breadth is the weighted average (weighted by each population's demand) over all species present. Guild diet breadth compares the summed use of nectar by all birds collectively with distribution of all possible nectar sources that month.

$\dagger$ Mean overlap is the weighted mean (weighted by each population's demand) taken over all species present in a given habitat-month combination, of overlap between the resource use by each population and collective resource use by all others. 


\section{INTENSITY OF EXPLOITATIVE COMPETITION ON AVERAGE POPULATION}

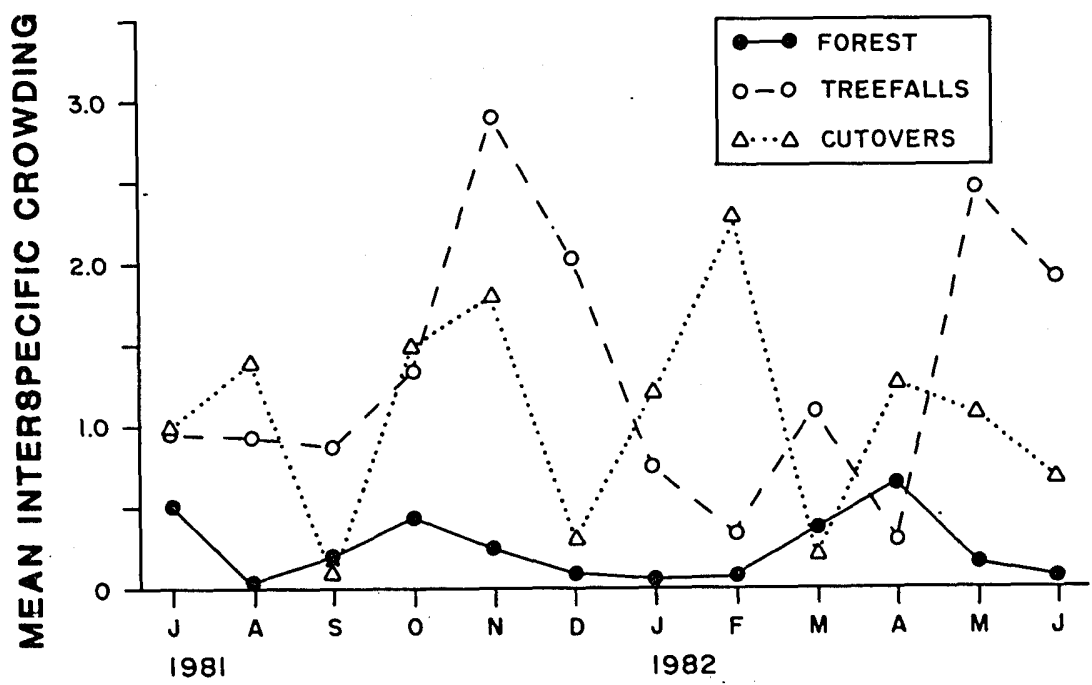

\section{MONTH}

Fig. 2.-Intensity of exploitative competition faced by the average hummingbird population in each of the three patch types over the 12 mo of this study. The level of exploitative competition was estimated with the co-occurrence coefficient or index of mean interspecific crowding, $z$ (eq. 8).

and their resources did vary among patch types, but direction of the variation was not the same in each case.

First, some variables reflected the "enriching" effect of moderate levels of disturbance. Treefalls, the most frequent natural disturbances, created more highly enriched patches than either cutovers (analogues of the largest naturally occurring disturbances) or forest understory (tables 1, 2, 4, 6). Canopy gaps created by treefalls have more light (and probably more nutrients) than forest understory (Orians 1982; Chazdon and Fetcher 1984; Brokaw 1985b; Canham and Marks 1985) but less rigorous physical conditions (and less severely perturbed soil) than large gaps (Connell and Slatyer 1977). Here, hummingbird-pollinated treefall plants, many of them resprouts or survivors of the disturbance event, flowered more profusely than plants in the other two patch types (see table 1; details in Linhart et al. 1987). Local enrichment of the nectar resource base led to local increases in density and diversity of avian consumers (tables 1, 2, 4).

Thus, like the sea palm Postelsia palmaeformis (Paine 1979) and the subtidal algae and invertebrates discussed by Sousa $(1980,1984 a)$, many apparent "equilibrium" populations in cloud forest, whether consumers or producers, actually thrive on frequent small-scale disturbances. Unlike the marine examples, however, individuals of cloud-forest plants have long generation times relative to the disturbance cycle; accompanied by their hummingbird mutualists, many persist as the canopy closes over a particular site, and are still in evidence by the time (often 
quite short) the next disturbance occurs. Also, most populations of birds and plants spill over into the somewhat more rigorous conditions of large gaps.

Some variables we examined, in fact, reflected increasing disruptiveness of disturbance in the sequence of forest, treefalls, cutovers, rather than reflecting the enriching effect of treefalls (tables 2, 6). Transient hummingbirds appeared in cutovers more often than in treefalls or forest (table 3). Although transients had little quantitative impact, collectively the resident bird populations also responded differentially to patch types, with those in gaps foraging more haphazardly in relation to one another and to available resources than those in forest. Compared to forest, cutovers were characterized by (1) high variation in demand for nectar resources (table 2); (2) low guild-wide diet breadth (match between collective foraging and nectar resources available; table 6); and (3) high diet overlap experienced by the average population (table 6 ). Both treefalls and cutovers, but not forest, were characterized by (4) intense exploitative competition (table 6) and, if results from the unreplicated flower-introduction experiment are valid, by (5) rapid discovery and exploitation of novel resources. Elsewhere we evaluate possible effects of this spatial variation in hummingbird foraging on the pollination ecology of their food plants (Feinsinger et al. 1987).

The increased "looseness" of species interactions in forest gaps barely hints at the volatility of hummingbird-nectar interactions. in tropical old fields. There, density of nectar resources may vary 20 -fold (Feinsinger 1976) or 100-fold (Feinsinger et al. 1985) annually, versus the 4-fold variation reported here (fig. 1); species diversity of consumers fluctuates greatly in response; nectar is demonstrably superabundant at some seasons, severely limiting at others (Feinsinger et al. 1985); and diet overlaps (Feinsinger 1976) or competitive intensities (Feinsinger et al. 1985) fluctuate widely from season to season, often reaching values considerably higher than those we found in any patch type of the cloud forest.

In fact, at the species level, cloud-forest hummingbirds did not reflect underlying habitat heterogeneity, at least not in the ways expected from conventional theory. For example, diet breadth of the average population in forest exceeded that of the average population in either type of gap (table 6), contrary to theory (Southwood 1977) and data (Brown and Southwood 1983) on populations of consumers in anthropogenic disturbance mosaics. Most surprisingly, disturbance within the cloud forest did not favor phenotypes more generalized than those existing in mature patches. This result characterized hummingbirds (tables 2,3 , 5), and also the plants pollinated by hummingbirds: plants with long flowers, specialized for pollination by hummingbirds with long, curved bills, were more frequent, not less frequent, in large disturbances (cutovers and landslides) than in forest (Linhart et al. 1987). In contrast, comparisons between forests and anthropogenic second-growth communities ("tropical old fields") have shown that the latter are characterized by phenotypes adapted for opportunistic use of resources (e.g., Opler et al. 1980), for example, short-billed hummingbirds and short-flowered plants (Stiles 1975, 1978, 1981; Feinsinger 1976, 1978, 1983; Feinsinger et al. 1982, 1985). Likewise, generalized phenotypes among herbivorous insects (Southwood 1977; Brown and Southwood 1983; Brown 1984) and northtemperate birds (May 1982) are associated with large anthropogenic disturbances, specialized phenotypes with undisturbed habitat. Apparently, disturbance within 
our study site did not disrupt the interactions between forest hummingbirds and their nectar resources severely enough for hummingbird "weeds" to invade, even though such birds are abundant only a short flight away.

In general, then, cloud-forest hummingbirds rarely exhibited the "community heterogeneity" often expected of organisms in disturbance mosaics. Species composition varied remarkably little among patch types; except for the infrequent transients, there were no true gap specialists (tables 3,5 ). Why did so little heterogeneity exist among the bird assemblages of the three patch types we examined? At least three possibilities exist. (1) The scale we examined was inappropriate: highly mobile, energy-demanding, widely foraging animals like hummingbirds are unlikely to respond to environmental patchiness of a relatively small scale. (2) The Monteverde cloud forest is idiosyncratic, not representative of most natural disturbance mosaics. (3) Unlike landscapes affected by human activities, the natural disturbance mosaic we studied lacked disturbances so intense or so physically atypical as to prevent local species from effectively exploiting the resulting patches.

First, hummingbirds fly freely among patches of the size range we studied, and encounter the cloud forest's disturbance mosaic in fine-grained fashion. Nevertheless, that hummingbirds can fly among patches does not mean they have to forage in each (see "Choice of System," above) or make the same foraging choices in each (see table 6). In anthropogenic disturbance mosaics, the boundary between a patch of forest and a patch of second growth often separates very different hummingbird assemblages even when some flowering plant species extend across both habitats (Stiles 1975, 1978, 1981; Feinsinger 1976; Feinsinger et al. 1985). Recent clearings at the boundaries of the Monteverde Cloud Forest Reserve, near our study sites, now support numerous hummingbirds of species that never penetrate into the forest (Feinsinger, pers. obs.). Evidence that hummingbirds respord to anthropogenic disturbance mosaics and other evidence on flexibility in their foraging choices provided no reason a priori for expecting them to ignore patch boundaries within a natural disturbance mosaic. Schemske and Brokaw (1981), comparing Panamanian birds in natural treefalls and forest understory, emphasized that eight bird species, including the hummingbird Threnetes ruckeri, were distributed differently between treefalls and forest. Thus, inappropriate scale cannot be the chief explanation for our results.

Second, even though the Monteverde cloud forest experiences high rates of disturbance, it is not anomalous. Close examinations of other forests, both Neotropical and temperate, reveal similar rates of disturbance (reviews in Whitmore 1982; Brokaw 1985b; Runkle 1985; Murray 1986). Our forest and treefall plots, at least, were representative of canopied forest and natural treefall gaps throughout the Monteverde cloud forest and, in general features, at other Neotropical sites we have examined (e.g., tropical wet forest at the La Selva Biological Station, Costa Rica; montane rain forest at Estación Biológica Coréa, near Cali, Colombia). It could be argued that some features we ascribe to large gaps were artifacts of the "cutover" technique. Considering hummingbirds' food resources and resource use, though, cutovers resembled naturally occurring, large gaps (regenerating landslide scars) nearby. For example, the preponderance of long flowers in cutovers (table 1) was mirrored on landslide scars (Linhart et al. 1987) 
even though some different species were involved. Therefore, our results cannot be dismissed on the basis of an idiosyncratic study site.

The likely explanation for our results is that the landscape we studied, and perhaps other natural landscapes as well, rarely experiences the sorts of disturbance that lead to pronounced community heterogeneity in all biotic elements. In the Monteverde cloud forest, small-scale disturbances are frequent today and presumably have been so in the past. Small gaps concentrate activity of both plants and animals, but larger gaps, such as landslide scars, are not so extremely different from intact forest as to preclude local populations or favor entirely different sets of species. Close examination of the few other studies on vertebrates' response to natural disturbance mosaics supports this conclusion. For example, in Schemske and Brokaw's (1981) study, 26 of 31 bird species having large sample sizes (including 3 of 4 hummingbird species with $N \geq 3$ ) were not differentially distributed between treefall gaps and forest understory. In a similar study, 33 of 44 species frequently mist-netted in a north-temperate deciduous forest showed no differential response to gaps and understory (Blake and Hoppes 1986). Likewise, no Panamanian bird species sampled by Willson et al. (1982) was differentially distributed between forest interior and treefall gaps.

Thus, nectar-feeding birds in the Monteverde cloud forest, and perhaps other animals and plants that inhabit tropical or temperate communities experiencing frequent natural disturbances, may be accommodated to frequent disturbances as long as these are of moderate intensity and likely to return rapidly to a mature phase. Such species, however, cannot often persist through catastrophic or chronic disturbances created by humans. Referring to old fields of northeastern North America, Marks (1983) pointed out that most studies on secondary succession have involved large anthropogenic tracts of second-growth vegetation rather than natural disturbance mosaics (e.g., Pickett 1976; Opler et al. 1980; Southwood et al. 1983). These anthropogenic gaps draw in species previously restricted to drier or more highly stressed sites (see also Ewel 1980; Kellman 1980), rather than species that evolved in the local landscape. Although old-field species may historically have persisted as small populations on physically stressed sites (Marks 1983), in landscapes altered by human activity they become "weeds" by virtue of previously existing life history traits and, in some cases, evolutionary changes.

Likewise, the short-billed, opportunistic hummingbird "weeds" that now occupy anthropogenic second growth in the Neotropics may have evolved in the boom-and-bust nectar-resource regime of forest canopy (Feinsinger and Colwell 1978), as scavengers from insect-, bat-, and passerine-pollinated flowers in tropical dry forest (Wolf 1970), or in mountain chains subjected to frequent vulcanism (Stiles 1983). The widespread second-growth vegetation that they and other "weeds" now inhabit makes for interesting and objective ecological experiments, but species interactions there may not represent events on natural landscapes unaffected by humans.

Many natural landscapes experience frequent disturbance on a small scale: Disturbance loosens or disrupts relations between species, or between species 
and resources, characteristic of intact communities. One result is the release of previously scarce resources, leading to increased productivity and increased intensity of species interactions in disturbed patches as compared with undisturbed patches. Additionally, populations in disturbed sites may exploit resources in a more haphazard and opportunistic fashion than populations in undisturbed sites. The altered ecological conditions of disturbed sites may favor species different from those occupying undisturbed sites, leading to spatial heterogeneity in community composition.

Nectar-feeding birds (mainly hummingbirds) inhabiting the natural disturbance mosaic of a Costa Rican cloud forest responded to habitat heterogeneity in complex ways. Whereas most ecological traits of hummingbird assemblages varied among patch types (understory of canopied forest; treefall gaps; large, landslide-like gaps), the direction of variation differed for different traits. Density of hummingbird food (nectar) was highest in treefall gaps, and some characteristics of hummingbirds (e.g., species diversity) reflected this enrichment. Variables that involve collective foraging by the entire hummingbird assemblage (e.g., intensity of interspecific competition) suggest that species interactions in the forest are the least haphazard, those in treefall gaps more haphazard, and those in large gaps the most haphazard. Even the largest gaps examined, however, were rarely invaded by hummingbird "weeds" available in the regional species pool, and interactions in these gaps showed only faint resemblance to those in the tremendously fluctuating competitive environments that characterize nectar-feeding bird assemblages in large anthropogenic old fields nearby or at other tropical sites. Our results, and reconsideration of results from other studies involving natural disturbance mosaics, suggest that responses of consumers to disturbance mosaics may often be subtle and complex. Comparisons between patch types in a natural disturbance mosaic need not resemble comparisons between points in a successional sequence after anthropogenic disturbance.

\section{ACKNOWLEDGMENTS}

C. A. Guindon, R. Shuster, K. S. Winnett-Murray, and especially J. A. Wolfe contributed to the data set. Personnel of the Centro Científico Tropical, especially J. A. Tosi, Jr., in San José and W. Guindon at Monteverde, facilitated our use of the Monteverde Cloud Forest Reserve. Personnel of the Organization for Tropical Studies, especially Roxana Díaz, helped with logistics. We thank M. L. Crump, C. Martínez del Rio, J. A. Pounds, D. R. Strong, Jr., J. N. Thompson, and four very patient reviewers for comments on various drafts. The study was funded through National Science Foundation grants DEB 80-11008 (to P.F.) and DEB 8011023 (to Y.B.L.).

\section{LITERATURE CITED}

Adams, C. C. 1908. The ecological succession of birds. Auk 25:109-153.

August, P. V. 1983. The role of habitat complexity and heterogeneity in structuring tropical mammal communities. Ecology 64:1495-1507.

Baldwin, S. P., H. C. Oberholser, and L. G. Worley. 1931. Measurements of birds. Cleveland Museum of Natural History, Cleveland, Ohio. 
Barton, A. M. 1986. Spatial variation in the effect of ants on an extrafloral nectary plant. Ecology 67:495-504.

Blake, J. G., and W. G. Hoppes. 1986. Influence of resource abundance on use of tree-fall gaps by birds in an isolated woodlot. Auk 103:328-340.

Brokaw, N. V. L. 1985a. Gap-phase regeneration in a tropical forest. Ecology 66:682-687.

- 1985b. Treefalls, regrowth, and community structure in tropical forests. Pages 53-69 in Pickett and White 1985.

Brown, V. K. 1984. Secondary succession: insect-plant relationships. BioScience 34:710-716.

Brown, V. K., and T. R. E. Southwood. 1983. Trophic diversity, niche breadth and generation times of exopterygote insects in a secondary succession. Oecologia (Berl.) 56:220-225.

Canham, C. D., and P. L. Marks. 1985. The responses of woody plants to disturbance: patterns of establishment and growth. Pages 197-216 in Pickett and White 1985.

Chazdon, R. L., and N. Fetcher. 1984. Photosynthetic light environments in a lowland tropical rain forest in Costa Rica. J. Ecol. 72:553-564.

Chesson, P. L., and T. J. Case. 1986. Overview: nonequilibrium community theories: chance, variability, history, and coexistence. Pages 229-239 in Diamond and Case 1986.

Connell, J. H. 1978. Diversity in tropical rain forests and coral reefs. Science (Wash., D.C.) 199:13021310.

Connell, J. H., and R. O. Slatyer. 1977. Mechanisms of succession in natural communities and their role in community stability and organization. Am. Nat. 111:1119-1144.

Denslow, J. S. 1980. Gap partitioning among tropical rainforest trees. Biotropica 12 (Suppl.):47-55.

Diamond, J., and T. J. Case, eds. 1986. Community ecology. Harper \& Row, New York.

Ewel, J. 1980. Tropical succession: manifold routes to maturity. Biotropica 12 (Suppl.):2-7.

Feinsinger, P. 1976. Organization of a tropical guild of nectarivorous birds. Ecol. Monogr. 46:257-291. 1977. Notes on the hummingbirds of Monteverde, Cordillera de Tilaran, Costa Rica. Wilson Bull. 89:159-164.

1978. Interactions between plants and hummingbirds in a successional tropical community. Ecol. Monogr. 48:269-287.

1983. Coevolution and pollination. Pages 282-310 in D. J. Futuyma and M. Slatkin, eds. Coevolution. Sinauer, Sunderland, Mass.

Feinsinger, P., and R. K. Colwell. 1978. Community organization among Neotropical nectar-feeding birds. Am. Zool. 18:779-795.

Feinsinger, P., and L. A. Swarm. 1982. "Ecological release," seasonal variation in food supply, and the hummingbird Amazilia tobaci on Trinidad and Tobago. Ecology 63:1574-1587.

Feinsinger, P., E. E. Spears, and R. W. Poole. 1981. A simple measure of niche breadth. Ecology 62:27-32.

Feinsinger, P., J. A. Wolfe, and L. A. Swarm. 1982. Island ecology: reduced hummingbird diversity and the pollination biology of plants, Trinidad and Tobago, West Indies. Ecology 63:494506.

Feinsinger, P., L. A. Swarm, and J. A. Wolfe. 1985. Nectar-feeding birds on Trinidad and Tobago: comparison of diverse and depauperate guilds. Ecol. Monogr. 55:1-28.

Feinsinger, P., J. H. Beach, Y. B. Linhart, W. H. Busby, and K. G. Murray. 1987. Disturbance, pollinator predictability, and pollination success among Costa Rican cloud forest plants. Ecology 68:1294-1305.

Garwood, N. C., D. P. Janos, and N. Brokaw. 1979. Earthquake-caused landslides: a major disturbance to tropical forests. Science (Wash., D.C.) 205:997-999.

Gill, F. B. 1978. Proximate costs of competition for nectar. Am. Zool. 18:753-763.

Gurney, W. S. C., and R. M. Nisbet. 1978. Predator-prey fluctuations in patchy environments. J. Anim. Ecol. 47:85-102.

Hallë, F., R. A. Oldeman, and P. B. Tomlinson. 1978. Tropical trees and forests: an architectural analysis. Springer-Verlag, New York.

Hartshorn, G. S. 1980. Neotropical forest dynamics. Biotropica 12 (Suppl.):23-30.

Hollander, M., and D. A. Wolfe. 1973. Nonparametric statistical methods. Wiley, New York.

Hubbell, S. P., and R. B. Foster. 1986. Biology, chance, and history and the structure of tropical rain forest tree communities. Pages 314-329 in Diamond and Case 1986. 
Huffaker, C. B. 1958. Experimental studies on predation: dispersion factors and predator-prey oscillations. Hilgardia 27:343-383.

Hurlbert, S. H. 1978. The measurement of niche overlap and some relatives. Ecology 59:67-77.

. 1984. Pseudoreplication and the design of ecological field experiments. Ecol. Monogr. 54: 187-211.

Janzen, D. H. 1973. Sweep samples of tropical foliage insects: effects of seasons, vegetation types, elevation, time of day, and insularity. Ecology 54:687-708.

Johnston, D. W., and E. P. Odum. 1956. Breeding bird populations in relation to plant succession on the Piedmont of Georgia. Ecology 37:50-62.

Karr, J. R. 1968. Habitat and avian diversity on strip-mined land in east-central Illinois. Condor 70:348-357.

Karr, J. R., and K. E. Freemark. 1983. Habitat selection and environmental gradients: dynamics in the "stable" tropics. Ecology 64:1481-1494.

1985. Disturbance and vertebrates: an integrative perspective. Pages 153-168 in Pickett and White 1985.

Kellman, M. 1980. Geographic patterning in tropical weed communities and early secondary successions. Biotropica 12 (Suppl.):34-39.

Lang, G. E., and D. H. Knight. 1983. Tree growth, mortality, recruitment, and canopy gap formation during a 10-year period in a tropical moist forest. Ecology 64:1075-1080.

Lawton, R., and V. Dryer. 1980. The vegetation of the Monteverde Cloud Forest Reserve. Brenesia 18:101-116.

Levin, S. A. 1974. Dispersion and population interactions. Am. Nat. 108:207-228.

1976. Population dynamics models in heterogeneous environments. Annu. Rev. Ecol. Syst. 7:287-310.

Linhart, Y. B., P. Feinsinger, J. H. Beach, W. H. Busby, K. G. Murray, W. Z. Pounds, S. Kinsman, C. Guindon, and M. Kooiman. 1987. Disturbance and predictability of flowering patterns in bird-pollinated cloud forest plants. Ecology 68:1696-1710.

MacArthur, R. H., and E. R. Pianka. 1966. On optimal use of a patchy environment. Am. Nat. 100:603-609.

Margalef, R. 1963. On certain unifying principles in ecology. Am. Nat. 97:357-374.

Marks, P. L. 1983. On the origin of the field plants of the northeastern United States. Am. Nat. 122:210-228.

May, P. G. 1982. Secondary succession and breeding bird community structure: patterns of resource utilization. Oecologia (Berl.) 55:208-216.

McIntosh, R. P. 1980. The relationship between succession and the recovery process in ecosystems. Pages 11-62 in J. Cairns, ed. The recovery process in damaged ecosystems. Ann Arbor Scientific, Ann Arbor, Mich.

M'Closkey, R. T. 1975. Habitat succession and rodent distribution. J. Mammal. 56:950-954.

Murray, K. G. 1986. Consequences of seed dispersal for gap-dependent plants: relationships between seed shadows, germination requirements, and forest dynamics processes. Pages 187-198 in T. H. Fleming and A. Estrada, eds. Frugivores and seed dispersal. Junk, Dordrecht, The Netherlands.

Odum, E. P. 1950. Bird populations of the highlands (North Carolina) plateau in relation to plant succession and avian invasion. Ecology 31:587-605.

. 1969. The strategy of ecosystem development. Science (Wash., D.C.) 164:262-269.

Opler, P. A., H. G. Baker, and G. W. Frankie. 1980. Plant reproductive characteristics during secondary succession in Neotropical lowland forest ecosystems. Biotropica 12 (Suppl.): $40-46$.

Orians, G. H. 1982. The influence of tree-falls in tropical forests on tree species richness. Trop. Ecol. 23:255-279.

Paine, R. T. 1979. Disaster, catastrophe, and local persistence of the sea palm Postelsia palmaeformis. Science (Wash., D.C.) 205:685-687.

Paine, R. T., and S. A. Levin. 1981. Intertidal landscapes: disturbance and the dynamics of pattern. Ecol. Monogr. 51:145-178.

Pickett, S. T. A. 1976. Succession: an evolutionary interpretation. Am. Nat. 110:107-119. 
Pickett, S. T. A., and J. N. Thompson. 1978. Patch dynamics and the design of nature reserves. Biol. Conserv. 13:27-37.

Pickett, S. T. A., and P. S. White, eds. 1985. The ecology of natural disturbance and patch dynamics. Academic Press, New York.

Platt, W. J., and I. M. Weis. 1977. Resource partitioning and competition within a guild of fugitive prairie plants. Am. Nat. 111:479-513.

1985. An experimental study of competition among fugitive prairie plants. Ecology 66:708720.

Rathcke, B. J. 1976. Competition and coexistence within a guild of herbivorous insects. Ecology 57:76-87.

Reddingius, J., and P. J. den Boer. 1970. Simulation experiments illustrating stabilization of animal numbers by spreading of risk. Oecologia (Berl.) 5:240-284.

Richards, P., and G. B. Williamson. 1975. Treefalls and patterns of understory species in a wet lowland tropical forest. Ecology 56:1226-1229.

Runkle, J. R. 1985. Disturbance regimes in temperate forests. Pages 17-33 in Pickett and White 1985.

Schemske, D. W., and N. Brokaw. 1981. Treefalls and the distribution of understory birds in a tropical forest. Ecology 62:938-945.

Schowalter, T. D. 1985. Adaptations of insects to disturbance. Pages 235-252 in Pick :tt and White 1985.

Schulz, J. P. 1960. Ecological studies on rainforest in northern Surinam. North Holland, Amsterdam.

Siegel, S. 1956. Nonparametric statistics for the behavioral sciences. McGraw-Hill, New York.

Sousa, W. P. 1980. The responses of a community to disturbance: the importance of successional age and species' life histories. Oecologia (Berl.) 45:72-81.

$1984 a$. Intertidal mosaics: patch size, propagule availability, and spatially variable patterns of succession. Ecology 65:1918-1935.

1984b. The role of disturbance in natural communities. Annu. Rev. Ecol. Syst. 15:353-391.

1985. Disturbance and patch dynamics on rocky intertidal shores. Pages 101-124 in Pickett and White 1985.

Southwood, T. R. E. 1977. Habitat, the templet for ecological strategies? J. Anim. Ecol. 46:337-366.

Southwood, T. R. E., V. K. Brown, and P. M. Reader. 1979. The relationships of plant and insect diversities in succession. Biol. J. Linn. Soc. (Lond.) 12:327-348.

1983. Continuity of vegetation in space and time: a comparison of insects' habitat templet in different successional stages. Res. Popul. Ecol. (Kyoto Univ.) Suppl. 3:61-74.

Stiles, F. G. 1975. Ecology, flowering phenology, and hummingbird pollination of some Costa Rican Heliconia species. Ecology 56:285-301.

1978. Temporal organization of flowering among the hummingbird food-plants of a tropical wet forest. Biotropica 10:194-210.

1981. Geographical aspects of a bird-flower coevolution, with particular reference to Central America. Ann. Mo. Bot. Gard. 68:323-351.

1983. Systematics of the southern forms of Selasphorus (Trochilidae). Auk 100:311-325.

Stiles, F. G., and L. L. Wolf. 1973. Techniques for color-marking hummingbirds. Condor 75:244-245.

Strong, D. R., Jr. 1983. Natural variability and the manifold mechanisms of ecological communities. Am. Nat. 122:636-660.

1986. Density vagueness: abiding the variance in the demography of real populations. Pages 257-268 in Diamond and Case 1986.

Strong, D. R., Jr., and M. F. Antolin. In press. Density vagueness and patchiness. In N. Stenseth and J. Swinggland, eds. Living in a patchy environment. Oxford University Press, Oxford.

Teraguchi, S., M. Teraguchi, and R. Upchurch. 1977. Structure and development of insect communities in an Ohio old-field. Environ. Entomol. 6:247-257.

Thompson, J. N. 1982. Interaction and coevolution. Wiley, New York.

Thompson, J. N., and M. F. Willson. 1978. Disturbance and the dispersal of fleshy fruits. Science (Wash., D.C.) 200:1161-1163.

Thomson, J. D., and K. A. Rusterholz. 1982. Overlap summary indices and the detection of community structure. Ecology 63:274-277.

Väisänen, R. A., and O. Järvinen. 1977. Dynamics of protected bird communities in a Finnish archipelago. J. Anim. Ecol. 46:891-908. 
Van Valen, L. 1978. The statistics of variation. Evol. Theory 4:33-43.

White, P. S. 1979. Pattern, process and natural disturbance in vegetation. Bot. Rev. 45:229-299.

White, P. S., and S. T. A. Pickett. 1985. Natural disturbance and patch dynamics: an introduction. Pages 3-13 in Pickett and White 1985.

Whitmore, T. C. 1978. Gaps in the forest canopy. Pages 639-655 in P. B. Tomlinson and M. H. Zimmermann, eds. Tropical trees as living systems. Cambridge University Press, New York. 1982. On pattern and process in forests. Pages 45-59 in E. I. Newman, ed. The plant community as a working mechanism. Spec. Publ. 1, British Ecological Society. Blackwell, Oxford.

Whittaker, R. H., and S. A. Levin. 1977. The role of mosaic phenomena in natural communities. Theor. Popul. Biol. 12:117-139.

Wiens, J. A. 1976. Population responses to patchy environments. Annu. Rev. Ecol. Syst. 7:81-120. 1985. Vertebrate responses to environmental patchiness in arid and semiarid ecosystems. Pages 169-193 in Pickett and White 1985.

1986. Spatial scale and temporal variation in studies of shrubsteppe birds. Pages 154-172 in Diamond and Case 1986.

Willson, M. F., E. A. Porter, and R. S. Condit. 1982. Avian frugivore activity in relation to forest light gaps. Caribb. J. Sci. 18:1-6.

Wolf, L. L. 1970. The impact of seasonal flowering on the biology of some tropical hummingbirds. Condor 72:1-14. 